\title{
The Construct Validity of Felder-Soloman Index of Learning Styles (ILS) for the Prospective Teachers*
}

\author{
Felder-Soloman Öğrenme Stili Ölçeği'nin \\ Öğretmen Adayları İçin Yapısal Geçerliği
}

\author{
Çiğdem Suzan Çardak ${ }^{1}$ \\ Anadolu University \\ Kıymet Selvi² \\ Anadolu University
}

\begin{abstract}
Learning style as one of the most important individual differences explains the features of individuals' learning process and defines the ways of their own learning. Among the various learning style indexes, the ILS of Felder-Soloman is one of the most preferred ones. Because the ILS was developed for engineering students, it is important to examine whether this instrument could be used for the students of faculty of education or not. In this study, it was aimed to test the construct validity of the ILS for the students of a faculty of education at Anadolu University in Turkey. According to the results of the Confirmatory Factor Analysis (CFA), the 44-item original structure of the ILS did not present a model fit with the data at hand. Indeed, the low reliability of one dimension of the scale showed that ILS could not be used as a valid and reliable scale for the participated prospective teachers.
\end{abstract}

Keywords: Learning Style, Index of Learning Styles (ILS), Confirmatory Factor Analysis

\section{Özet}

Öğrenme sürecine ilişkin önemli bir bireysel farklılık olan öğrenme stili, öğrenenin öğrenme özelliklerini ve öğrenme sürecinde tercih ettiği yolları ifade eden bir kavramdır. Alanyazında yer alan öğrenme stillerini belirlemeye yönelik pek çok araç içinde FelderSoloman'ın Öğrenme Stili Ölçeği en çok tercih edilenlerden biridir. Bu ölçek mühendislik fakültesi öğrencilerinin öğrenme stillerini belirlemek için geliştirildiğinden, ölçeğin eğitim fakültesi öğrencilerinin öğrenme stillerinin belirlenmesinde kullanılıp kullanılamayacağının incelenmesi gerekli görülmüştür. Bu çalışmada, Felder-Soloman Öğrenme Stili Ölçeği'nin

\footnotetext{
* This study was presented at the First International Congress on Curriculum and Instruction, Eskişehir, 5-8 October, 2011.

${ }^{1}$ Assist.Prof.Dr. Anadolu University, Faculty of Education, csbelikusakli@anadolu.edu.tr

2 Prof.Dr. Anadolu University, Faculty of Education, kselvi@anadolu.edu.tr
} 
Anadolu Üniversitesi Eğitim Fakültesi öğrencileri için yapısal geçerliğinin test edilmesi amaçlanmıştır. Doğrulayıcı Faktör Analizi (DFA) sonucuna göre 44 maddelik ölçeğin eldeki veri ile uyum sergilemediği görülmüştür. Ayrıca ölçeğin bir boyutuna ilişkin güvenirlik indeksinin oldukça düşük çıkması, bu ölçeğin çalışmaya katılan eğitim fakültesi öğrencileri için geçerli ve güvenilir bir ölçme aracı olarak kullanılamayacağını göstermiştir.

Anahtar Sözcüler: Öğrenme stili, Felder-Soloman Öğrenme Stili Ölçeği, Doğrulayıcı Faktör Analizi

\section{Introduction}

It is very important for individuals to have information regarding their own features of learning during the process of learning to learn. Learning style is such an important term that explains the features of individuals' learning process and defines the ways of their own learning. In the literature, there are various learning style models and indexes based on these models. Among the learning style models, Kolb, Dunn and Dunn, Hanson-Silver, Gregorc, Grasha and Riechmann, Canfield, Honey and Mumfort, Felder-Silverman, Paragon learning style models could be counted (Claxton \& Murrell, 1987; Felder \& Silverman, 1988; Ekici, 2002; Güven, Çardak, Sever \& Vural, 2008; Güven \& Çardak, 2014; Honey \& Mumford, 1995; Silver, Strong \& Perini, 2000).

Considering the learners' education level, various learning style models were studied for Turkish context and related scales were adapted into Turkish. Indeed, adaptation studies related to some of the scales of various learning style models were conducted with the participation of Turkish prospective teachers (e.g. Akgün et al., 2014; Dağhan \& Akkoyunlu, 2011; Doğan \& Çermik, 2012; Vural, 2013). Besides, in the literature related to Turkish prospective teachers' learning styles, Kolb Learning Style Model (e.g. Açışlı, 2016; Can, 2011; Canvas, 2010; Özdemir, 2014), Grasha-Reichman Learning Style model (e.g. Deniz, 2013; Narli, Aksoy \& Ercire, 2014; Yeşilyurt, 2014) and Gregorg Learning Style Model (e.g. Topuz \& Karamustafaoğlu, 2013; Yenice \& Saracaloğlu, 2009) draw the attention.

Apart from widely known learning style models such as Kolb, Dunn and Dunn, or Gregorg, Felder-Silverman (1988) Learning Style Model gains popularity in recent years. This model explains the learning preferences of the students through focusing on different aspects of a learning process, which were referred as perceiving and understanding the information. Such comprehensive learning style models might help both learners and instructors to design learning-teaching processes in more detail. Indeed, if the learning preferences of the student could be identified, designing the learning materials and activities accordingly might result in more effective learning.

ILS of Felder-Soloman (2004) is based on the learning style model of Felder-Silverman so that it determines the learning preferences of the students in a very comprehensive way. Additionally, ILS has been used for identifying the learning preferences of the student studying especially on engineering. ILS is 
also one of the most preferred learning style indexes by the adaptive educational hypermedia system developers (Akbulut \& Cardak, 2012). The future of the education is foreseen to be depended on such systems and the success of ILS for adaptive educational hypermedia should be considered not only for the engineering students but also for the students of faculty of education.

Though the ILS was previously adapted into Turkish Language for the engineering student by Arslan (2003), its soundness for the prospective teachers needs future validity and reliability studies for the sake of ILS's original target learner group who were engineering students. This valuable instrument could be helpful for prospective teachers only if its previously well-defined structural model is valid for them. Thus, it is important to examine whether this instrument could be used for determining the learning styles of the students of faculty of education or not. In this study, it was aimed to test the construct validity of ILS for the prospective teachers. It is hoped that the results of the study will be helpful for future studies regarding the ILS.

\section{Felder-Silverman Learning Style Model}

Felder and Silverman (1988) defined the learning style through five dimensions each with two poles which corresponds to two features of learning related to specific dimension for the learning styles of the engineering students. The five dimensions and their two poles were perception dimension with sensory and intuitive poles, input dimension with visual and auditory poles, organization dimension with inductive and deductive poles, processing dimension with active and reflective poles, and finally understanding dimension with sequential and global poles. Later on, the organization dimension was excluded from the model and the auditory feature of learning of the input dimension was changed as verbal learners (Felder, 2002).

The final version of the learning style model is composed of four dimensions and two features of learning within each one. Perception dimension means the type of information that a student prefer to perceive in two ways; sensory or intuitive. The second one, the input dimension means the sensory channel while perceiving the information; visual or verbal. Processing dimension refers to the ways of processing the information; active or reflective, and finally the understanding dimension is related to the progress of the learners during the understanding period; sequential or global. These dimensions of Felder and Silverman's model identifies the process of receiving and processing the new information to be learned and proposes related teaching styles to help the learners with different features of learning (Felder and Silverman, 1988). Figure 1 shows the learning style dimensions and the corresponding teaching styles. 


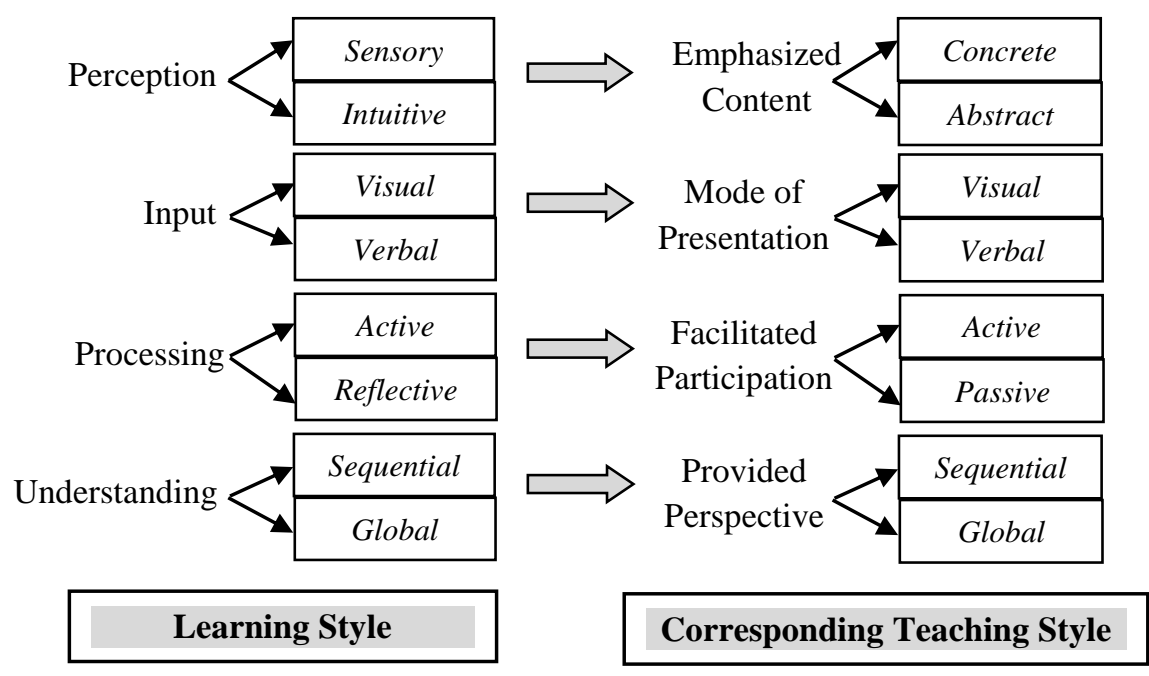

Figure 1. Dimensions of Learning Styles and Corresponding Teaching Styles

This figure was derived from the table created by Felder and Silverman (1988, p. 675).

As showed on Figure 1, there are various teaching styles corresponding to related learning styles. In this context, if an instructor generally teaches according to his/her dominant learning style, some of the students might fail because of their different learning presences other than the instructor's. It means matching the teaching styles of the instructor with the related learning styles of the students might result in more effective learning-teaching processes. The related literature also supports this claim through various empirical evidences (e.g. Ford and Chen, 2001; Bajraktarevic, Hall, \& Fullick, 2003; Bozkurt and Aydoğdu, 2009; Hsieh, Jang, Hwand and Chen, 2011; Mustafa and Sharif, 2011). Thus, it has become important to identify the learning styles of the students and design learning-teaching activities accordingly. One of the mostly used valid and reliably ways of identifying the learning styles is the selfreport instruments. The ILS is one of the self-report instrument used by the researchers and educators as a valid and reliable scale.

\section{The Structure of the ILS}

ILS of Felder and Soloman (2004) is designed to assess the preferences of the learners for each of four dimensions of Felder-Silverman Learning Style Model (Felder and Soloman, 2004; Litzinger, Lee, Wise, and Felder, 2005). It is defined as an online questionnaire and two important issues related to the index 
are highlighted to make caution. Firstly ILS results provide the preferences of the learners, secondly ILS results "provide an indication of possible strengths and possible tendencies or habits that might lead to difficulty in academic settings" (Felder and Soloman, 2004). In this regard, the produced student profile by the ILS does not indicate the suitable or unsuitable subjects for the students or does not refer labeling the students according to their preferences.

ILS has 44 items for active/reflective, sensing/intuitive, visual/verbal, sequential/global dimensions of the Felder-Silverman Learning Style Model. Thus, ILS with four learning style dimensions has four sub-scales. Each dimension has 11 questions with bipolar choice indicating two learning preferences. It means the learners have to choose "a" or " $b$ " but not both for the answer of each question. Below question is taken from the original ILS in order to exemplify (Soloman and Felder, nd.):

Question 3: When I think about what I did yesterday, I am most likely to get

(a)a picture.

(b) words.

A learner can gain scores from 1 to 3,5 to 7 or 9 to 11 for each scale. Scores 1-3 mean the learner is fairly well balanced on two poles of the specific dimension. Scores 5-7 refer to moderate preference on the pole that the learner preferred and scores 9-11 mean the strong preference for one pole of the learning style dimension (Felder-Soloman, 2004). For instance, if a learner's score on visual-verbal scale is 1 to 3 on the verbal side, this means the learner's preference for being verbal is mild, at times she/he could prefer visual learning material as much as verbal materials. If the learner's score is 9 to 11 on verbal pole, the learner has a strong preference for verbal learning.

\section{Methods}

\section{Sample}

470 students of the Faculty of Education at Anadolu University from the $1^{\text {st }}$ to $4^{\text {th }}$ grades attending various teacher education programs at departments of primary education, foreign language education, computer education and instructional technologies participated in the study. The prospective teachers were selected randomly and all of them participated in the study voluntarily.

\section{Data Collection}

The process of testing the construct validity of Felder-Soloman Index of Learning Styles for the students of faculty of education began with examining the previously adapted version of the ILS into Turkish by Arslan (2003). In this regard, the adapted version of the ILS was examined by considering the original version of the index. The Turkish version of the ILS adapted by Arslan (2003) was decided to be used in this study because of the high correlation between 
the Turkish and the original indexes (Arslan, 2003; Arslan and Aksu, 2006). Meanwhile, the necessary permissions were taken for the adaptation of the index for the students of faculty of education both from Dr. Felder and Dr. Arslan. The previously adapted version of the ILS by Arslan (2003) was applied to the sample. It took approximately 20 minutes to fill in the index and fully answered 431 indexes without missing values were taken for analysis.

\section{Data Analysis}

In order to confirm the construct validity of the ILS for the prospective teachers, Confirmatory Factor Analysis (CFA) was conducted. CFA was performed using Lisrel 8.7 statistical package for testing the four factor-model of the ILS. Because of the variable type being nominal (dichotomous classification scale; "a" or "b", but not both), correlation and asymptotic covariance matrices with "weighted least squares" method were used (Şimşek, 2007). During the CFA study, seven operations were conducted to test the model of ILS. Three criteria were followed for assessing the model: T-values, the error variances and goodness-of-fit indices were controlled. Firstly all of the t-values were checked and variables with insignificant $t$-values at the significance level of .05 were excluded from the model. Then error variances were examined and the observed variables which had error values higher than 0.94 were excluded from the model one by one. Finally goodness-of-fit indices of the model were examined. For the internal consistency of the each dimensions of the ILS, KR-20 values were calculated. The reliability values were compared with the results of the other studies.

\section{Results}

In the current study, CFA was started from testing the original ILS model which has 44-item four dimensional structure each consisting of 11-items. Table 1 shows the original model of ILS.

Table 1. The Latent and Observed Variables of the Original 44-item ILS

\begin{tabular}{ll}
\hline Dimensions of the ILS & Item Numbers \\
\hline Processing: Active/Reflective Learners & $1-5-9-13-17-21-25-29-33-37-41$ \\
\hline Perceiving: Sensing/Intuitive Learners & $2-6-10-14-18-22-26-30-34-38-42$ \\
\hline Input: Visual/Verbal Learner & $3-7-11-15-19-23-27-31-35-39-43$ \\
\hline Understanding: Sequential/Global Learners & $4-8-12-16-20-24-28-32-36-40-44$ \\
\hline
\end{tabular}


To test the construct validity of the model of ILS given on Table 1, seven operations were conducted to find the best data fit of the model. Table 2 shows the number of operations on ILS, items with insignificant t-values, excluded items from the model and $\mathrm{x}^{2}$ values obtained.

Table 2. Tests of ILS, Excluded Items from the ILS and Obtained $x^{2}-$ Values

\begin{tabular}{|c|c|c|c|c|}
\hline $\begin{array}{l}\text { Operation } \\
\text { No }\end{array}$ & Tested ILS & $\begin{array}{c}\text { Items with } \\
\text { insignificant } \\
\text { t-values }\end{array}$ & $\begin{array}{l}\text { Excluded items } \\
\text { from the ILS }\end{array}$ & $\mathbf{x}^{2}$ \\
\hline 1 & ILS $_{(44-\text {-item })}$ & $\begin{array}{c}\text { Item8- Item10- } \\
\text { Item12- Item17- } \\
\text { Item39 }\end{array}$ & - & 1712.81 \\
\hline 2 & ILS $_{(39-\text { item })}$ & - & $\begin{array}{c}\text { Item8- Item10- } \\
\text { Item12- Item17- } \\
\text { Item39 }\end{array}$ & 1240.55 \\
\hline 3 & ILS $_{(38-\text { item })}$ & - & Item20 & 1186.88 \\
\hline 4 & ILS $_{(37-\text { item })}$ & - & Item 16 & 1106.50 \\
\hline 5 & ILS (36-item) & - & Item44 & 1058.24 \\
\hline 6 & ILS $_{(35-\text { item) }}$ & - & Item35 & 948.21 \\
\hline 7 & ILS (34-item) & - & Item43 & 910.38 \\
\hline
\end{tabular}

According to Table 2, the first operation was conducted to test the 44-item structure of the four dimensional model and the test results gave five items (810-12-17-39) with insignificant t-values. Indeed, the obtained $x^{2}$ value was considerably high for the 44-item model. Furthermore, the error variances of these observed variables with insignificant t-values were 1.00, 1.00, .99, 1.00 and .99 respectively. According to those results, 44-item ILS did not revealed a model fit with the data at hand.

In such cases in which there are insignificant $t$ values and high error variances, Çokluk, Şekercioğlu and Büyüköztürk (2010) advice to exclude related observed variables from the model after checking their error variances. Similarly, Şimşek (2007) makes caution about excluding such items from the model. Based on the related literature on CFA, before proceeding with the second operation of CFA study, these five items with t-values higher than 1.96 at the significance 
level of .05 were excluded from the model. According to the Table 2, after the first operation, none of the remaining operations gave insignificant $t$-values. Thus, error values were checked in each operations.

After eliminating five items because of t-values and very high error variances, the second operation was conducted to test the 39-item ILS model. According to the result of the second operation, $x^{2}$ value was dramatically decreased $\left(x^{2}=1240.55\right)$. Even though the respectively low value of the $x^{2}$, when error values were examined, items with error values higher than .94 were identified. Beginning from the highest error value, related items were eliminated from the model one by one starting from the Item-20.

The following operations (operation three to seven) were conducted in the same manner as the second one. As showed on Table 2, after each operation, $x^{2}$ value was decreased and took its lowest value $\left(x^{2}=910.38\right)$ as a result of the last (the seventh) operation. The CFA study regarding the model of the ILS was resulted with the seventh operation because of having all of the $t$-values significant and error values lower than .94 as a result of the last operation. Although .94 value is also respectively high regarding error variances, the concern of content validity made the researchers result the CFA study after eliminating Item 43 as the last item excluded from the model. At total, 10 items were excluded from the model according to the CFA study of ILS through seven operations. Some of the goodness-of-fit indices of the 44-item ILS and the final situation of the ILS with 34-item were given on Table 3. Additionally, the result of Chi-square test with Chi-square values and the ratio of Chi-square value to the degree of freedom were also given on Table 3.

Table 3.The Goodness-of-fit Indices of the First and the Seventh Tests Regarding the ILS

\begin{tabular}{cccccccccc}
\hline $\begin{array}{c}\text { Tested } \\
\text { ILS }\end{array}$ & $\mathbf{x}^{\mathbf{2}}$ & $\mathbf{d f}$ & $\mathbf{p}$ & $\mathbf{x}^{\mathbf{2}} / \mathbf{d f}$ & GFI & AGFI & CFI & RMR & RMSEA \\
\hline ILS (44-item) & 1712.81 & 896 & .000 & 1.912 & .92 & .91 & .54 & .065 & .046 \\
\hline ILS $_{(34-\text { item) }}$ & 910.38 & 521 & .000 & 1.747 & .94 & .94 & .69 & .063 & .042 \\
\hline
\end{tabular}

According to the Table 3, there was a considerable decrease on the $x^{2}$ value from the first CFA test for the original 44-item ILS to the seventh test with 34item one. On the other hand, both of the $\mathrm{x}^{2}$ tests were significant as usually occurred on CFA studies even though insignificant results were expected. However "the chi-square index and its $p$-value alone cannot be fully trusted in general as means for model evaluation" (Raykov and Marcoulides, 2006, p. 43.). Because $x^{2}$ statistic is sensitive to sample size (Kelloway, 1998), other parameters were reported here such as $x^{2} / d f$. According to Şimşek (2007), the 
value of $x^{2} / d f$ lower than two indicates a good model fit to the observed data. As showed on Table 3, both of the CFA tests gave the lower than two value for $x^{2} / d f\left(1.747\right.$ for 34 -item ILS). Hence $x^{2} / d f$ value of the 34 -item ILS might be taken as an evidence for good fit of the model to the data.

Among the other fit indices, GFI (Goodness of Fit Index), AGFI (Adjusted Goodness of Fit Index) and CFI (Comparative Fit Index) bigger than .90 indicate acceptable fit of the model to the data (Şimşek, 2007; Yılmaz and Çelik, 2009). In this study, GFI and AGFI indices kept the value higher than .90 while CFI value remained lower than .90 although it increased considerably. According to Yet, West, Finc and Curan (1995), CFI value is quite reliable to make predictions regarding data with normal distribution which is not the case in this study (Cited in Şimşek, 2007). When GFI and AGFI indices were considered to make predictions regarding model fit of the ILS to the data, 34-item ILS showed better fit.

Among the other indices, RMR (Root Mean Square Residual) should be below .05 for acceptable fit (Şimşek, 2007). As showed on Table 4, even though RMR index did not decreased below.05, it took its smallest value of .063 as a result of the seventh test with 34-item ILS. In this study RMSEA (Root Mean Square Error of Approximation) index which is among the most informative indices and gaining popularity (Kelloway, 1998; Raykov and Marcoulides, 2006) might be taken as the predictor of the model fit since RMSEA values less than .05 indicated the good-fit of the model to the data (Kelloway, 1998) as it is the case for this study. RMSEA took its smallest value (.042) on the seventh CFA operation with 34-item ILS. On Table 4, the sub-scales and the numbers of the remaining items on each were showed.

Table 4. The Latent and Observed Variables of the 34-item ILS

\begin{tabular}{llc}
\hline Dimensions of the ILS & Item Numbers & Total \\
\hline Processing: Active/Reflective Learners & $1-5-9-13-21-25-29-33-37-41$ & 10 \\
\hline Perceiving: Sensing/Intuitive Learners & $2-6-14-18-22-26-30-34-38-42$ & 10 \\
\hline Input: Visual/Verbal Learner & $3-7-11-15-19-23-27-31$ & 8 \\
\hline Understanding:Sequential/Global Learners & $4-24-28-32-36-40$ & 6 \\
\hline
\end{tabular}

As indicated on Table 4, one item from the processing dimension, similarly only one item from the perceiving dimension was excluded from the scale. On the other hand, three items from the input dimension and five items from the understanding dimension were excluded from the ILS. The original 11-item structure on each sub-scale was highly destroyed as a result of the CFA study. 
However, this 34-item structure might cause some problems in terms of interpretation of the scores gathered from the ILS. Meanwhile, excluding five items from the understanding dimension might weaken the content validity of the last dimension. On Figure 2, the path diagram of the 34-item ILS was given.

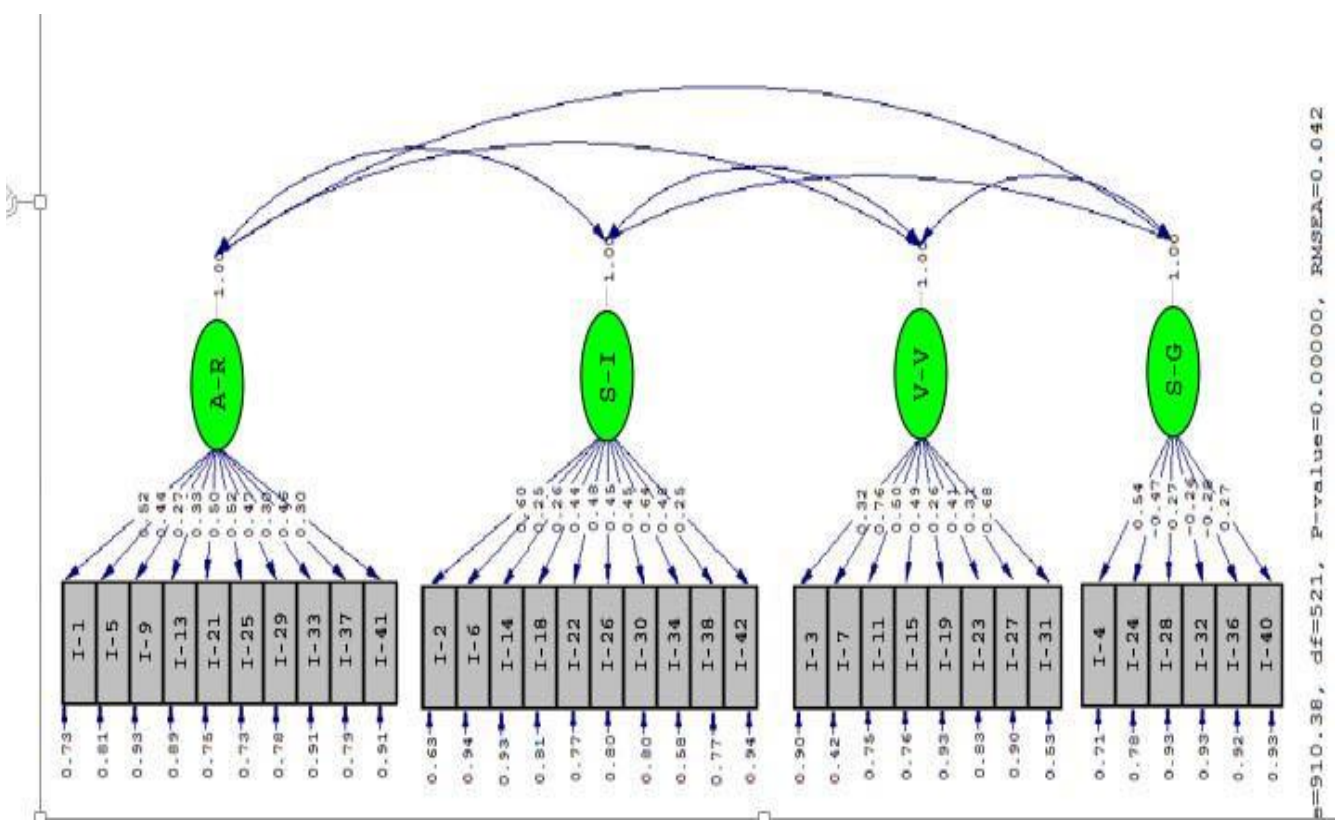

Figure 2. Path Diagram of the 34-item ILS

According to the results of the CFA study, the seventh operation regarding the 34-item ILS might show the best fit to the data at hand though the concern of content validity. Nevertheless, before claiming anything about the validity, the internal reliability ratios of the ILS had been calculated and interpreted.

\section{Internal Consistency Reliability}

The internal consistency reliability of the Turkish Felder-Soloman ILS for the prospective teachers was calculated as KR-20 value and found to be 0.60 for the whole of the instrument. On Table 5 , the reliability ratios of the each dimension of the ILS were compared with other studies. 
Table 5. Comparisons of the Internal Consistency Reliability Ratios of the ILS

\begin{tabular}{|c|c|c|c|c|c|}
\hline & $\mathbf{N}$ & $\mathbf{A} / \mathbf{R}$ & $\mathbf{S} / \mathbf{I}$ & $\mathbf{v} / \mathbf{v}$ & $\mathbf{S} / \mathbf{G}$ \\
\hline \multicolumn{6}{|l|}{ Studies Conducted in Turkey } \\
\hline Arslan (2003) & 120 & .49 & .55 & .53 & .30 \\
\hline Samancı and Keskin (2007) & 381 & .43 & .54 & .59 & .32 \\
\hline Atman et al. (2009) & 408 & .50 & .56 & .61 & .47 \\
\hline Aktürk et al. (2013) & 113 & .63 & .50 & .67 & .29 \\
\hline Current Study & 431 & .56 & .58 & .53 & .20 \\
\hline \multicolumn{6}{|l|}{ Other Studies } \\
\hline $\begin{array}{l}\text { Van Zwanenberg, Wilkinsin and } \\
\text { Anderson }(2000)\end{array}$ & 279 & .51 & .65 & .56 & .41 \\
\hline Zywno (2003) & 557 & .60 & .70 & .63 & .53 \\
\hline Litzinger et al. (2005) & 572 & .60 & .77 & .74 & .56 \\
\hline Platsidou and Metallidou (2009) & 340 & .45 & .62 & .51 & .45 \\
\hline Hosford and Siders (2010) & 358 & .63 & .76 & .64 & .62 \\
\hline $\begin{array}{l}\text { Al-Azawei, Parslow and Lundqvist } \\
\text { (2015) }\end{array}$ & 259 & .41 & .57 & .59 & .43 \\
\hline
\end{tabular}

A/R: Active/Reflective, S/I: Sensing/Intuitive, V/V: Visual/Verbal, S/G: Sequential/G/obal

As given on Table 5, the reliability ratios of the ILS in Turkey were near each other for all of four dimensions. Despite that, sequential/global dimension had very low internal consistency reliability in the studies conducted with Turkish students and the current study had the lowest value (.20) for this dimension. The study conducted by Atman et al. (2009) reported the highest reliability of sequential/global dimension of the ILS (Cited in Aslan, Öztürk and İnceoğlu, 2014). Additionally, comparing to the other dimensions, sequential/global dimension had almost the lowest internal consistency 
reliabilities in all studies showed on Table 5 regardless of being conducted in Turkey or not. Reliability values of the other dimensions of the ILS in the study at hand were .56 for the active/reflective dimension, .58 for sensing/intuitive dimension, .53 for visual/verbal dimension. Other studies reported almost similar reliability ratios for the other three dimensions of the ILS especially in Turkey.

\section{Discussion and Conclusion}

In the current study, CFA was conducted to understand the construct validity of the previously defined structure of the ILS for the prospective teachers at Anadolu University. The 44-item four dimensional model of the ILS was tested with the data at hand to find out the model fit which was defined as "the extent to which a hypothesized model is consistent with the data" (Diamantopoulos and Siguaw, 2000, p. 82). According to Çokluk et al. (2010), cross-cultural scale adaptation studies could start directly with CFA study only if the scale's factorial structure was validated in its original culture. ILS, as one of the most popular instruments of learning styles and preferences, was validated by various studies (eg. Zywno, 2003; Felder and Spurlin, 2005; Litzinger, Lee, Wise \& Felder, 2007).

According to results of the CFA study, 44-item four dimensional model of ILS did not present a model fit with the data at hand because of some items with insignificant t-values and very high error variances. Similarly, in another study which was conducted to reveal the soundness of the ILS for Arabic sample, the results of factor analysis was not promising (Al-Azawei et al., 2015). Actually, such results are expectable because of cultural differences and boost the need for developing original scales of learning styles specific for each culture.

When the CFA study was continued, 34-item four dimensional model of ILS produced more acceptable model fit to the data collected from prospective teachers at Anadolu University. However 34-item ILS might not be convenient with the 44-item original structure of the ILS since 44-item is separated into four dimensions so each dimension has 11-item in order to make the highest scores equal for each sub-scales. Therefore, the final version of the ILS revealed in the current study might cause difficulty to the learner while interpreting the learning preferences. Indeed, the content validity of the scale especially for the last dimension in which five items were excluded required future studies.

Although the goodness of fit-indices of 34-item ILS were promising, before deciding on the construct validity of the 34-item ILS, reliability study in means of internal consistency was considered. The results of the internal consistency reliabilities of the four dimensions of the ILS showed that apart from the sequential/global dimension, the reliability values of the other dimensions were acceptable. On the other hand, 0.20 value for the reliability of the sequential/global dimension was very low. Similarly, in other studies conducted in Turkey related to the ILS also reported very low reliability values for the last dimension of the ILS (Arslan 2003; Samancı and Keskin, 2007; Aktürk et al. 2013). The reason of the low reliability values of the understanding dimension 
(sequential/global learners) might be the same as the current study; the content organization of the curricula in Turkey generally follow sequential paths and Turkish students get used to take information sequentially. The fact that was revealed in Turkish studies might be taken as a caution for curriculum developers. Curriculum developers should consider global learners when organizing the content through starting with the cases, aims and objectives, summaries or other learning materials to help the students understand the big picture before proceeding with detail information sequentially. Educational psychologist should also take the results revealed in the studies in Turkey regarding the low reliability values of the sequential/global dimension as a need for further studies. In this context, the conformity of sequential/global dimension of the ILS to Turkish Culture should be critically reviewed. In the future studies, this dimension might be excluded from the model or the items of this dimension might be re-written for Turkish Culture.

Other three dimensions of the ILS have acceptable reliabilities because all a bit above 0.50 (Tuckman, 1999). Therefore excluding the sequential/global dimension and using the three-dimensional ILS might be considered in order to determine the learning styles of the prospective teachers in future studies. However, taking the ILS with three dimensional structure requires future validity and reliability studies with new data, because the data was collected in the current study based on four-dimensional ILS. When three-dimensional ILS was applied to the prospective teachers, more different results might be revealed.

While the reliability values of the each dimension of the ILS were considered, the reliability of the index as a whole was found to be .60 which could be interpreted as a moderate value for a self-report instruments. The twopolar scale of the ILS might have affected the reliability because the participants must have selected "a" or " $b$ " option, not both, for each item on the ILS. Similarly, another learning style instrument which has similar structure with ILS, Paragon Learning Style Inventory (PLSI), had very low reliability values for Turkish context too (Çardak \& Güven, 2014). For the future studies, exploratory factor analysis might be conducted on ILS after augmenting the response options for each item at least to five-scale grading.

Apart from internal consistency reliability, the strength of the ILS on determining the learning styles is also questionable because of being a selfreport instrument. New trends on adaptive educational hypermedia which accommodates learning styles are based on determining students' learning preferences automatically by using the system's records on students' behaviors. The results regarding the learning styles derived from such automatic learning style detection systems are convenient with the results of ILS (Garcia, Amandi, Schiaffino, and Campo, 2007; Özpolat and Akar, 2009; Dung and Florea, 2012; Latham, Crockett, Mclean, and, Edmonds, 2012; Feldman, Monteserin, and Amandi, 2014). Thus, in order to verify the strength of ILS on learning style identification, prospective teachers' learning behaviors during adaptive online learning processes might be observed and the results might be compared with the result of ILS for the future studies. 
As a conclusion, the construct validity of the 44-item ILS was not obtained for the participant prospective teachers of the current study. Even though the 34-item ILS model were found to be promising as a result of the CFA study with the data at hand, the concern of content validity with 34-item ILS and the low reliability value of the fourth dimension of the index requires further studies in order to decide the reliability and validity of the four dimensions of the ILS for the prospective teachers and Turkish Culture.

\section{Acknowledgement}

The authors would like to thank to Dr. Richard Felder, Dr. Berna Arslan and Dr. Meral Aksu for their kindly permissions to use ILS.

\section{References}

Açışlı, S. (2016). Sınıf Öğretmeni Adaylarının Öğrenme Stilleri ile Eleştirel Düşünme Eğilimlerinin İncelenmesi [Investigation of Class Teacher Candidates' Learning Styles and Critical Thinking Dispositions]. Elementary Education Online, 15(1), 273-285. Doi:10.17051/io.2016.78596.

Akbulut, Y., and Cardak, C. S. (2012). Adaptive educational hypermedia accommodating learning styles: A content analysis of publications from 2000 to 2011. Computers \& Education, 58(2), 835-842. Doi:10.1016/j.compedu.2011.10.008.

Akgün, Ö. E., Küçük, Ş., Çukurbaşı, B., and Tonbuloğlu, İ. (2014). Sözel veya Görsel Baskın Öğrenme Stilini Belirleme Ölçeği Türkçe Formunun Geçerlik ve Güvenirlik Çalışması [Validity and Reliability Study of the Visual versus Verbal Style of Processing Scale Turkish Form]. Bartın Üniversitesi Eğitim Fakültesi Dergisi, 3 (1), 277 - 297. Doi:10.14686/BUEFAD.201416218.

Aktürk, Z., Acemoglu, H., Set, T., Cansever, Z., and Avsar, U. Z. (2013). Turkish reliability and validity of the Index Learning Styles instrument. HealthMED, 7(2), 445-450.

Al-Azawei, A., Parslow, R., and Lundqvist, K. (2015). A Psychometric Analysis of Reliability and Validity of the Index of Learning Styles (ILS). International Journal of Psychological Studies, 7(3), 46-57. DOI: http://dx.doi.org/10.5539/ijps.v7n3p46.

Arslan, B. (2003). A descriptive study on learning style preferences of the engineering students at METU. Unpublished Master's Thesis, Middle East Technical University, Institute of Social Sciences, Ankara.

Arslan, B., and Aksu, M. (2006). A descriptive study of the learning style profiles of the engineering students at the Middle East Technical University (METU). Education and Science, 31 (141), 83-91. 
Aslan, B. G., Öztürk, Ö., and İnceoğlu, M. M. (2014). Effect of Bayesian Student Modeling on Academic Achievement in Foreign Language Teaching (University Level English Preparatory School Example). Educational Sciences: Theory \& Practice, 14(3), 1143-1168.

Atman, N., İnceoğlu, M. M., Öğretmen, T., and Aslan, B. G. (2009, Mayıs). Felder ve Soloman Öğrenme Biçemi Ölçeği etkin-yansıtıcı ve görsel-sözel boyutlarının geçerlik ve güvenirlik çalışması. [Validity and reliability study of visual-verbal dimensions of ILS]. Paper presented at the First International Congess on Turkish Educational Studies, Çanakkale 18 Mart University.

Bajraktarevic, N., Hall, W., and Fullick, P. (2003). Incorporating learning styles in hypermedia environment: Empirical evaluation. In P. de Bra, H. C. Davis, J. Kay \& M. Schraefel (Eds.), Proceedings of the Workshop on Adaptive Hypermedia and Adaptive Web-Based Systems (pp. 4 1-52). Nottingham, UK.

Bozkurt, O., and Aydoğdu, M. (2009). A comparative analysis of the effect of Dunn and Dunn Learning Styles Model and traditional teaching method on 6th grade students' achievement levels and attitudes in science education lesson. Elementary Education Online, 8(3), 741-754.

Can, Ş. (2011). Sınıf öğretmeni adaylarının öğrenme stilleri ile bazı değişkenler arasındaki ilişkinin araştırılması [Investigations of the relationships between the learning styles of the preservice elementary teachers and some variables]. H. U. Journal of Education, 41, 70-82.

Canvas, B. (2010). A study on pre-service science, class and mathematics teachers' learning styles in Turkey. Science Education International, 21(1), 47-61.

Claxton, C. S., and Murrell, P. H. (1987). Learning Styles: Implications for Improving Educational Practices. ASHE-ERIC Higher Education Reports. Retrieved from http://eric.ed.gov/?id=ED293478 26 March 2016.

Çardak, Ç. S., and Güven, M. (2014). Assessment of the reliability and validity of PLSI in a Turkish Higher Education Institution. Anadolu Journal of Educational Sciences International, 4(2), 108-132.

Çokluk, Ö., Şekercioğlu, G., and Büyüköztürk, Ş. (2010). Sosyal Bilimler İçin Çok Değişkenli İstatistik: SPSS ve LISREL Uygulamaları. [Multi Variable Statistics for Social Sciences]. Ankara: Pegem Akademi.

Dağhan, G., and Akkoyunlu, B. (2011). Maggie mcvay lynch öğrenme stili envanterinin türkçe'ye uyarlanma çalışması [The adaptation study of Maggie Mcvay Lynch Learning Style Inventory into Turkish]. H. U. Journal of Education, 40, 117-126.

Deniz, S. (2013). Öğretmen adaylarının öğrenme stilleri ve öğretmen öz-yeterlik algı düzeylerinin bazı değişkenler açısından incelenmesi [An investigation of the learning styles and teacher self-efficacy levels of perception of pre- 
service teachers according to various variables]. International Online Journal of Educational Sciences, 5 (3), 667-684.

Diamantopoulos, A., and Siguaw J. A. (2000). Introducing Lisrel. London: SAGE Publications Ltd.

Doğan, B., and Çermik, H. (2012). Nasıl Öğreniyorum Envanteri'nin Türkçe'ye uyarlanması: Geçerlik ve Güvenirlik Çalışması [The adaptation of how I Learn Inventory into Turkish: Validity and reliability studies. H. U. Journal of Education, 14, 154-163.

Dung, P. Q., and Florea, A. M. (2012). Preceedings of the International Conference on Education and Management Innovation, IPEDR vol.30, IACSIT Press, Singapore. Retrieved from http://www.ipedr.com/vol30/34ICEMI\%202012-M00065.pdf July 01, 2015.

Felder (2002). Author's Preface for the "Learning and Teaching Styles in Engineering Education". Engineering Education, 78(2): 674-681. Retrieved from

http://www4.ncsu.edu/unity/lockers/users/f/felder/public/Learning Styles.h tml, September 15, 2011.

Felder, R.M., and Silverman L.K. (1988). Learning and Teaching Styles in Engineering Education. Engineering Education, 78(2): 674-681.

Felder, R.M., and B.A. Soloman. (2004). Index of Learning Styles. Retrieved from

http://www4.ncsu.edu/unity/lockers/users/f/felder/public/ILSpage.html September 15, 2011.

Felder, R.M., and Spurlin (2005). Applications, Reliability and Validity of the Index of Learning Styles. International Journal of Engineering Education, 21(1), 103-112.

Feldman, J., Monteserin, A., and Amandi, A. (2014). Detecting students' perception style by using games. Computers \& Education, 71, 14-22. Doi:10.1016/j.compedu.2013.09.007.

Ford, N., and Chen, S.-Y. (2001). Matching/mismatching revisited: an empirical study of learning and teaching styles. British Journal of Educational Technology, 32(1), 5-22.

Garcia, P., Amandi, A., Schiaffino, S., and Campo, M. (2007). Evaluating Bayesian networks precision for detecting students learning styles. Computers \& Education, 49, 794-808. Doi:10.1016/j.compedu.2005.11.017.

Güven, M. Çardak, Ç. S., Sever, D., and Vural, L. (2008). Türkiye'de öğrenme stillerine ilişkin yapılan araştırmaların kullanılan envanterler boyutunda incelenmesi. [Investigations on research regarding learning styles in terms of inventories]. Proceedings of International Conference on Educational Sciences, ICES'08. North Cyprus, pp. 932-943. 
Honey, P., and Mumford, A. (1995). Honey ve Mumford Learning Styles Questionnaire: Facilitator Guide. King of Prussia, Pa.: Renaissance Boulevard.

Hosford, C. C., and Siders, W. A. (2010). Felder-Soloman's Index of Learning Styles: Internal consistency, temporal stability, and factor structure. Teaching and Learning in Medicine: An International Journal, 22(4), 298303. Doi: 10.1080/10401334.2010.512832.

Hsieh, S.-W., Jang, Y.-R., Hwand G.-Y., and Chen, N.-S. (2011). Effects of teaching and learning styles on students' reflection levels for ubiquitous learning. Computers \& Education, 57 (1), 1194-1201. Doi:10.1016/j.compedu.2011.01.004.

Kelloway, E. K. (1998). Using Lisrel for Structural Equation Modelling: $A$ Researcher's Guide. California: SAGE Publications, Inc.

Latham, A., Crockett, K., Mclean, D., and Edmonds, B. (2012). A conversational intelligent tutoring system to automatically predict learning styles. Computers \& Education, 59, 95-109. Doi:10.1016/j.compedu.2011.11.001.

Litzinger, T.A., Lee, S.H.; Wise, J.C., and Felder, R.M. (2005). A Study of the Reliability and Validity of the Felder-Soloman Index of Learning Styles, Proceedings, 2005 ASEE Annual Conference and Exposition.

Litzinger, T.A., Lee, S.H.; Wise, J.C., and Felder, R.M. (2007). A Psychometric Study of the Index of Learning Styles. Journal of Engineering Education, 96(4), 309-319.

Mustafa, Y.-E.-A., and Sharif, S. M. (2011). An approach to adaptive e-learning hypermedia system based on learning styles (AEHS-LS): Implementation and evaluation. International Journal of Library and Information Science, $3(1), 15-28$.

Narli, S., Aksoy, E., and Ercire, Y. E. (2014). Veri madenciliği ile ilköğretim matematik öğretmen adaylarının öğrenme stillerinin ve aralarındaki ilişkilerin incelenmesi [Investigation of prospective elementary mathematics teachers' learning styles and relationships between them using data mining]. International Journal of Educational Studies in Mathematics, (1), 37-57.

Özdemir, F. and Kaplan, A. (2014). Öğretmen adaylarının öğrenme stillerine göre matematiksel ispat hakkındaki görüslerinin incelenmesi [An analysis of prospective math teachers' thoughts about mathematical proof by learning styles]. Amasya Education Journal, 3(2), 410-429.

Özpolat, E. and Akar, G. B. (2009). Automatic detection of learning styles for an e-learning system. Computers \& Education, 53(2), 355-367. Doi:10.1016/j.compedu.2009.02.018.

Platsidou, M., and Metallidou, P. (2009). Validity and reliability issues of two learning style Inventories in a Greek sample: Kolb's Learning Style 
Inventory and Felder \& Soloman's Index of Learning Styles. International Journal of Teaching and Learning in Higher Education, 20(3), 324-335.

Raykov, T. and Marcoulides, G. A. (2006). A First Course in Structural Equation Modelling. Second Edition. New Jersey: Lawrence Erlbaum Associates, Inc.

Samancl, N.K. and Keskin, M.Ö. (2007). Felder ve Soloman Öğrenme Stili İndeksi: Türkçe'ye uyarlanması ve geçerlik-güvenirlik çalışması [FeldelSoloman Learning Style Index: Adaptation to Turkish and validity-reliability study]. Ahi Evran Üniversitesi Kırşehir Eğitim Fakültesi Dergisi, 8(2), pp.3754.

Silver, H. F., Strong, R. W., and Perini, M. J. (2000). Integrating Learning Styles and Multiple Intelligences. USA: Association for Supervision and Curriculum Development.

Soloman, B. A. and Felder, R. M. (nd.). Index of Learning Styles Questionnaire. North Carolina State University. Retrieved from http://www.engr.ncsu.edu/learningstyles/ilsweb.html January 5, 2016.

Şimşek, Ö. (2007). Yapısal Eşitlik Modellemesine Giriş: Temel İlkeler ve Lisrel Uygulamaları [Introduction to Structural Equation Modelling: Basic Principles and Lisrel Applications]. Ankara: Ekinoks.

Topuz, F. G., and Karamustafaoğlu, O. (2013). Öğrenme stillerinin çeşitli değişkenler açısından incelenmesi: fen bilgisi öğretmen adayları [Investigation of learning styles according to some variables: prospective science teachers]. Dicle Üniversitesi Ziya Gökalp Eğitim Fakültesi Dergisi, $21,30-46$.

Tuckman, B. W. (1999). Conducting Educational Research, 5th edition, Belmont, CA: Wadsworth Group.

Van Zwanenberg, N., Wilkinson, L. J., and Anderson, A. (2000). Felder and Silverman's Index of Learning Styles and Honey and Mumford's Learning Styles Questionnaire: How do they compare and do they predict academic performance?, Educational Psychology: An International Journal of Experimental Educational Psychology, 20(3), 365-380, DOI: $10.1080 / 713663743$.

Vural, L. (2013). Grasha-Riechmann Öğrenme Stili Ölçeği'nin yapı geçerliği çalışmaları. [Construct validation of Grasha-Riechmann Learning Style Scale]. Journal of Theory and Practice in Education, 9(4), 481-496.

Yenice, N., and Saracaloğlu, A. S. (2009). Sınıf öğretmeni adaylarının öğrenme stilleri ile fen başarıları arasındaki ilişki [The relationship between learning styles and science achievement of preservice elementary school teachers]. Yüzüncü Yıl Üniversitesi Eğitim Fakültesi Dergisi, 6(1), 162-173.

Yeşilyurt, E. (2014). Öğretmen adaylarının öğrenme stillerinin belirlenmesi ve öğrenme stilleri arasındaki ilişkinin değerlendirilmesi [Determination of 
teachers' learning styles and evaluation of the relationship among learning styles]. Journal of Theory and Practice in Education, 10(4), 999-1021.

Yılmaz, V., and Çelik, H. E. (2009). LISREL ile Yapısal Eşitlik Modellemesi -I: Temel Kavramlar, Uygulamalar, Programlama [Structural Equation Modeling with LISREL - I: Basic Concepts, Applications and Programming]. Ankara: Pegem Akademi.

Zywno, M. S. (2003). A contribution of validation of score meaning for FelderSoloman's Index of Learning Styles," Proceedings, 2003 Annual ASEE Conference and Exposition. Retrieved from http://citeseerx.ist.psu.edu/viewdoc/download?doi=10.1.1.167.7813\&rep=r ep1\&type=pdf October 10, 2013. 